\title{
Delaying Budbreak to Reduce Freeze Damage: Seasonal Vine Performance and Wine Composition in Two Vitis vinifera Cultivars
}

\author{
Meredith J. Persico, ${ }^{1}$ Donald E. Smith, ${ }^{1}$ and Michela Centinari ${ }^{1 *}$
}

\begin{abstract}
Spring freeze events pose a threat to vineyard productivity worldwide. We compared two methods to delay grapevine budbreak for freeze avoidance and evaluated their effects on phenology, yield components, fruit composition, and postharvest parameters, including wine chemistry, carbohydrate storage, and bud freeze tolerance. The two methods to delay budbreak were a vegetable oil-based adjuvant (Amigo) applied to dormant buds at $8 \%$ and $10 \%(\mathrm{v} / \mathrm{v})$ and late pruning applied when apical buds reached approximately Eichhorn-Lorenz stage 7. Treatments were applied in 2018 and 2019 on two Vitis vinifera cultivars, Lemberger and Riesling, and compared to a control treatment with no delayed budbreak strategy. Amigo and late pruning delayed budbreak compared to control vines in both years and cultivars. The delay in budbreak varied from three to six days for Amigo $8 \%$, five to eight days for Amigo 10\%, and 10 to 11 days later for late pruning. In 2019, there was a freezing event near budbreak. Compared to control vines, late-pruned Lemberger vines had less shoot damage when measured during the growing season and greater yield at harvest. Delayed budbreak treatments did not influence wine chemistry either year or consistently affect carbohydrate storage or bud freeze tolerance in the following dormant season. However, in Riesling, late pruning reduced cluster and berry weight by up to 34 and $22 \%$, respectively, compared to control vines. Furthermore, Amigo 10\% may decrease bud survival when applied to Riesling vines. In general, late pruning delayed budbreak more effectively and mitigated freeze damage better than Amigo application without negatively affecting vine health or wine composition; however, the cultivar-dependent effect of late pruning on cluster weight is a consideration prior to adoption.
\end{abstract}

Key words: carbohydrate reserve, cool climate, dormancy release, freeze stress, pruning, viticultural practice

Spring freeze events pose a significant economic threat to cool climate grape growing regions (Evans 2000, Warmund et al. 2008). As grapevines emerge from dormancy and approach budbreak, bud metabolism increases (Gardea et al. 1994) and bud freeze tolerance decreases (Ferguson et al. 2011, 2014, Kovaleski and Londo 2019). Post-budbreak, temperatures below freezing can damage tender young shoots permanently. If primary shoots are killed by freeze damage, secondary or tertiary buds will grow; however, these buds tend to be less

\footnotetext{
${ }^{1}$ The Pennsylvania State University, Department of Plant Science, 107 Tyson Building, University Park, PA 16802.

*Corresponding author (mzc22@psu.edu; tel: 814-867-0514; fax: 814-863-6139) Acknowledgments: This project was supported by the Pennsylvania Wine Marketing and Research Board Program, Timothy R. Crouch Program Support Endowment, and the USDA National Institute of Food and Agriculture (NIFA) Federal Appropriation under Project PEN0 4628 (Accession number 1014131). The authors would like to thank Dr. Charles Zaleski, MD, at Fero Vineyards and Winery for providing and maintaining the vineyard experimental site; Drs. Helene Hopfer and Molly Kelly for assistance with research winemaking; Dr. Rich Marini for consultation on statistical analysis; and all lab members for help with phenology and production data collection.
}

Manuscript submitted Dec 2020, revised April 2021, accepted May 2021

This is an open access article distributed under the CC BY license (https:// creativecommons.org/licenses/by/4.0/).

By downloading and/or receiving this article, you agree to the Disclaimer of Warranties and Liability. The full statement of the Disclaimers is available at http://www.ajevonline.org/content/proprietary-rights-notice-ajev-online. If you do not agree to the Disclaimers, do not download and/or accept this article. doi: 10.5344/ajev.2021.20076 fruitful, leading to significant reductions in yield (Friend et al. 2011). One strategy to mitigate spring freeze damage is to delay budbreak to later in the growing season, when the risk of freezing events has decreased.

Previously studied methods to delay grapevine budbreak include applying sodium alginate gels (Friend et al. 2011) or vegetable oil-based adjuvants (Dami and Beam 2004, Loseke et al. 2015, Centinari et al. 2018, Wang and Dami 2020) to vines during dormancy. These products are presumed to decrease bud respiration and therefore delay cold deacclimation, but evidence of their mode of action is not conclusive. It is reported that oil application reduces bud respiration, but this reduction is cultivar-dependent (Dami and Beam 2004) and certain oils may be phytotoxic, especially if applied above specific concentrations (Dami and Beam 2004, Centinari et al. 2018). In comparison, late pruning is an established method to delay budbreak for freeze avoidance (Howell and Wolpert 1978). In this method, pruning is not performed during the dormant season, or it is limited to the removal of several upper nodes per cane ("double pruning"). Maintaining apical buds until they break suppresses budbreak of the basal buds, which remain dormant longer. When the risk of freeze damage subsides, the apical buds are removed (i.e., late-pruned), initiating basal budbreak. While more convenient for cordontrained and spur-pruned vines, late or double pruning can also be adapted for cane-pruned vines by leaving the intended canes longer than needed and in an upright position; however, concerns of damaging swollen or broken buds when tying 
canes to the trellis and the extra labor and time needed for this operation may limit its adoption for cane-pruned vines.

Although it is a promising method to avoid freeze damage, delaying budbreak can shift other key phenological stages, including bloom and fruit set (Friend and Trought 2007). Delaying budbreak can also delay berry maturation (Frioni et al. 2016, 2019, Petrie et al. 2017), resulting in reduced fruit soluble sugar concentration at harvest and altered wine chemical composition (Moran et al. 2018). Delaying the onset of berry ripening is desirable in warm climates, where late pruning has been used to offset rapid sugar accumulation in fruit (Frioni et al. 2016, Moran et al. 2017, Palliotti et al. 2017, Petrie et al. 2017); however, effects of delaying budbreak on fruit and wine composition may be detrimental in cool climates, where the growing season is relatively short.

It is also unknown whether phenological shifts during the growing season delay vine cold acclimation and dormancy induction, including accumulation of total non-structural carbohydrates (TNC), which equal the sum of soluble sugars and starch, and the acquisition of bud freeze tolerance. Stored soluble sugars are important for bud freeze tolerance (Jones et al. 1999), and starch fuels growth the following spring (Holzapfel et al. 2010). If delaying budbreak delays canopy development and the onset of berry ripening, vines may prioritize photosynthate allocation to vegetative growth and fruit ripening, which are stronger sinks than storage allocation (Candolfi-Vasconcelos et al. 1994). Late-pruned vines may be especially vulnerable to reductions in TNC, as they must mobilize stored TNC reserves twice: once during apical budbreak and again during basal budbreak. Therefore, identifying strategies that consistently delay budbreak while maintaining vine health and fruit and wine quality is paramount to helping practitioners make informed freeze protection decisions.

This two-year study compared two methods to delay grapevine budbreak for freeze damage avoidance: application of a vegetable oil-based adjuvant at $8 \%$ and $10 \%$ (Amigo, Loveland Products, Inc.) and late pruning. The study was performed on Lemberger and Riesling, two Vitis vinifera cultivars relevant to cool climate winegrape growing (Ferguson et al. 2014). Our first objective was to examine whether these strategies delayed grapevine budbreak consistently and to evaluate the effects of delayed budbreak on within-season (e.g., phenology, berry development, and yield) and postharvest (e.g., wine chemistry, TNC accumulation, and bud freeze tolerance) parameters. If a freeze event occurred during the study period, we sought to evaluate the efficacy of our treatments in mitigating freeze damage. We tested two concentrations of Amigo ( $8 \%$ and $10 \%$ ) based on previous work conducted at the same research site, which indicated Amigo at $10 \%$ reduced bud survival (Centinari et al. 2018).

We hypothesized Amigo application and late pruning would delay grapevine budbreak and reduce spring freeze damage but also shift key phenological stages (e.g., bloom and veraison) with respect to control vines. Based on previous work conducted in cool climate regions (Dami and Beam 2004, Loseke et al. 2015, Wang and Dami 2020), we did not expect a shift in phenology to affect fruit composition at har- vest and wine chemistry, unless the delay in budbreak was extensive ( $>10$ to 14 days). However, we hypothesized that vines might prioritize fruit ripening at the expense of total TNC storage, which in turn could negatively affect bud freeze tolerance or growth the following spring.

\section{Materials and Methods}

Vineyard site and experimental design. This experiment was performed in 2018 and 2019 on two $V$. vinifera cultivars: 10-year-old Lemberger (red-fruited) and Riesling (white-fruited) vines growing in a commercial vineyard in Lewisburg, Pennsylvania (40 $57^{\prime} \mathrm{N}$; $76^{\circ} 53^{\prime} \mathrm{W}$; USDA hardiness zone 6b). The vineyard soil was classified as Washington siltloam (https://websoilsurvey.sc.egov.usda.gov/). Vines from each cultivar were grafted onto 101-14 Mgt rootstock and spaced $1.5 \mathrm{~m}$ apart; vineyard rows were north-south oriented and spaced $2.1 \mathrm{~m}$ apart. Vines were trained to a low-wire bilateral cordon at $0.80 \mathrm{~m}$, with vertical shoot-positioning. Shoot density was adjusted to 15 shoots per vine if they exceeded this number. All vines received standard cultural and disease control practices for $V$. vinifera in the eastern United States (Wolf 2008).

The experimental design was a randomized complete block design with four treatments and six replications per treatment. There were approximately eight contiguous vines in each experimental unit. Four consecutive rows of each cultivar were selected, and different rows were chosen in 2018 and 2019 to prevent additive treatment effects. The treatments were: 1) control (no delayed budbreak strategy applied), 2) Amigo (Loveland Products, Inc.) applied at $8 \%(\mathrm{v} / \mathrm{v})$ concentration during dormancy, 3) Amigo (Loveland Products, Inc.) applied at $10 \%(\mathrm{v} / \mathrm{v})$ concentration during dormancy, and 4) late pruning applied in both years when the three most-apical buds averaged stage 7, or "first leaf separated from shoot tip," on the Eichhorn-Lorenz (E-L) scale system (Coombe 1995), except for Riesling buds which averaged stage E-L 9, "two to three leaves separated," in 2018. Amigo is composed of $9.2 \%$ oil (soybean-based) and $0.7 \%$ emulsifier; the product was diluted with water to reach the desired $8 \%$ and $10 \%$ concentrations before application.

Vines assigned to the control and Amigo 8\% and 10\% treatments were spur pruned to two basal buds on 28 Feb 2018 and 13 March 2019, while vines assigned to late pruning were trimmed to the top catch wire on the same day ( $\sim 2 \mathrm{~m}$ high). Amigo $8 \%$ and $10 \%$ were applied with a backpack sprayer until runoff was observed on both sides of the canopy on 28 Feb 2018 and 18 March 2019; oil was applied before any significant heat accumulation occurred $(<10$ growing degree days [GDD], base $\left.10^{\circ} \mathrm{C}\right)$. Late pruning treatments were applied 7 May 2018 and 1 May 2019 for Lemberger and 11 May 2018 and 6 May 2019 for Riesling.

Weather parameters. Air temperature and rainfall were measured throughout the study with a weather station (MKIII, RainWise) at the site. GDDs (base $10^{\circ} \mathrm{C}$ ) were calculated as GDD $=$ [maximum daily temperature + minimum daily temperature)/2] - 10. To record the incidence of below-freezing events, wireless temperature dataloggers (iButton Fob, 
Model DS1921G-F5\#, accuracy $\pm 0.5^{\circ} \mathrm{C}$; Embedded Data Systems) with radiation shields were placed in each experimental unit on the first trellis wire, at the approximate height of the vine cordon. Air temperature was recorded every $20 \mathrm{~min}$ by the dataloggers from mid-March through April to capture potential spring freeze events.

Grapevine phenology and freeze damage. Four vines and either the north- or south-facing cordon were selected randomly in each experimental unit for phenological assessment. On each cordon, phenological growth stage was determined for each node using a modified E-L scale. Phenology measurements were conducted on the same buds approximately twice per week, starting about one week before control vines reached budbreak and ending shortly after control vines reached fruit set (E-L 27) in 2018 and full bloom (E-L 23) in 2019. Buds were deemed at budbreak when they were at E-L 5 , "rosette of leaf tips visible." For each date that phenology was recorded, the percentage of buds at or beyond budbreak was calculated for each experimental unit, and to estimate the date of $50 \%$ budbreak, the percentage of budbreak was interpolated between the last pre-budbreak and first post-budbreak dates. Therefore, the estimate assumes phenology was linear between the period before and post-budbreak, which is an approximation. A veraison assessment was conducted in Lemberger by visually determining the percentage of berries per cluster that changed color on the same vines selected for phenology on 15 Aug 2018 and 15 Aug 2019. The veraison assessment was not conducted on the Riesling vines.

A freezing event occurred on 29 April 2019, when the phenological stage of the Lemberger control averaged between E-L 3 and 4, "woolly buds" and "green leaf tips visible," respectively. Green tissue damage was assessed visually in Lemberger on the same vines selected for phenology about five weeks later (6 June 2019), when signs of freeze damage (i.e., leaf discoloration and necrosis) were clearly visible. Presence of green tissue damage on each shoot was evaluated either "yes" or "no." Freeze damage was not visible on Riesling and therefore not assessed.

Berry chemistry analysis. In each cultivar, 100 to 200 berries were randomly sampled in each experimental unit three times during fruit ripening, beginning near veraison and ending at harvest. Berry samples were placed on ice for transport from the vineyard and frozen at $-20^{\circ} \mathrm{C}$ until chemical analysis. To determine total soluble solids (TSS), $\mathrm{pH}$, and titratable acidity (TA) for each sample, frozen berries were first counted and weighed, then placed in a water bath at $60^{\circ} \mathrm{C}$ to thaw. The thawed berries were pressed for juice and strained through cheesecloth to remove solids as described (Homich et al. 2017). TSS was measured using a handheld refractometer (Master, Atago); $\mathrm{pH}$ was measured using a $\mathrm{pH}$ meter (Orion Star A111, Themo Fisher Scientific), and TA was measured using an automatic titrator (G20, Mettler Toledo), in which $10 \mathrm{~mL}$ of juice sample was diluted with $30 \mathrm{~mL}$ deionized water and titrated to $\mathrm{pH} 8.2$ using $0.10 \mathrm{~N}$ sodium hydroxide.

Yield components and vegetative growth. Vines were hand-harvested on the day of, or just prior to, commercial harvest: 3 Oct 2018 and 4 Oct 2019 for Lemberger; 26 Sept
2018 and 30 Sept 2019 for Riesling. Clusters of all vines in each experimental unit, except the first and last vines, were counted and weighed using a hanging scale accurate to $0.02 \mathrm{~kg}$ (ES-55 Electro, Samson Brecknell), from which average yield and cluster number per vine were calculated. Vines were spur pruned to five or six two-bud spurs per meter cordon on 13 March 2019 and 7 April 2020; pruning weights of all experimental vines were collected on the same day with a hanging scale accurate to $0.02 \mathrm{~kg}$ (ES-55 Electro, Samson Brecknell). Crop load was calculated and expressed as Ravaz index (yield/pruning weight).

Winemaking and wine chemical analysis. On the day of harvest, $\sim 375 \mathrm{~kg}$ Lemberger (each year) and $160 \mathrm{~kg}$ Riesling (2019 only) fruit was transported to the Pennsylvania State University Department of Food Science and stored overnight at $3^{\circ} \mathrm{C}$. Lemberger wines were made in 2018 and 2019, but Riesling wines only in 2019, due to a high level of fruit rot present across all treatments in 2018. In both years, Lemberger fruit was separated by treatment and divided into three winemaking replicates by combining grapes of two consecutive blocks (i.e., blocks 1 and 2, 3 and 4, and 5 and 6). Riesling grapes were pooled by treatment and fermented in duplicate due to an uneven volume of fruit among field blocks.

Lemberger fruit was crushed/destemmed the day after harvest using a stainless steel crusher and destemmer. The must from each winemaking replicate was then poured into open-top, low density polyethylene fermentation bins (Nalgene, Thermo Fisher Scientific), yielding between 12 and $30 \mathrm{~L}$ must per replicate. Riesling fruit was crushed and destemmed within $48 \mathrm{hrs}$ after harvest and pressed immediately in a vertical stainless steel hydraulic basket press, yielding between 11 and $22 \mathrm{~L}$ per treatment. Pressed Riesling juice was divided evenly into two glass carboys per treatment. For both cultivars, juice chemistry (TA, pH, and TSS) and yeast assimilable nitrogen (YAN) were measured on a $50 \mathrm{~mL}$ sample the day of crushing. YAN was determined by adding ammonia nitrogen and primary amino acid nitrogen values, which were determined separately using enzymatic test kits (Kits 4A120 and 4A110, respectively, Vintessential Laboratories). Before primary fermentation, each replicate was adjusted to $50 \mathrm{mg} / \mathrm{L}$ $\mathrm{SO}_{2}$ using potassium metabisulfite, and Lemberger 2018 must and Riesling 2019 juice were adjusted to 21 Brix using granulated sucrose. Then, Lemberger must and Riesling juice were inoculated with $0.25 \mathrm{~g} / \mathrm{L}$ Saccharomyces cerevisiae strain ICV-GRE (Lallemand) and rehydrated with $0.3 \mathrm{~g} / \mathrm{L}$ GoFerm (Scott Laboratories) for primary fermentation. YAN of each replicate was adjusted to $0.25 \mathrm{~g} / \mathrm{L}$ using Fermaid K (Lallemand) nutrient at one-third sugar depletion. Fermentations were considered complete when residual sugar concentration reached $<0.1 \%$, confirmed by Clinitest tablets (Bayer), followed by enzymatic quantification of glucose and fructose concentrations using a test kit (Kit 4A140, Vintessential Laboratories).

During primary fermentation, Lemberger pomace caps were punched down, and temperatures were measured three times daily, while TSS was measured once per day using a hydrometer. At dryness, each replicate was pressed into glass 
carboys using a vertical stainless steel hydraulic basket press, and a $250 \mathrm{~mL}$ wine sample was taken from each fermentation replicate and stored at $-20^{\circ} \mathrm{C}$. Lemberger wines were then inoculated with Oenococcus oeni Alpha MBR (Lallemand) for malolactic fermentation, which was monitored using paper chromatography. Malolactic fermentation was confirmed complete using an enzymatic assay for L-malic concentration (Kit 4A165, Vintessential Laboratories).

Both Lemberger and Riesling wines were adjusted to $0.8 \mathrm{mg} / \mathrm{L}$ molecular free $\mathrm{SO}_{2}$ based on $\mathrm{pH}$ prior to bottling, which occurred on 4 Feb 2019 (Lemberger 2018 vintage) and 18 and 19 Dec 2019 for Riesling and Lemberger 2019 vintage, respectively. For each cultivar, $250 \mathrm{~mL}$ wine samples were collected at bottling and frozen at $-20^{\circ} \mathrm{C}$. All wine samples were tested for alcohol, residual sugar, $\mathrm{pH}$, TA, malic acid, lactic acid, and volatile acidity using near-infrared technology (WineScan, Model 8388621, FOSS) and for free and total $\mathrm{SO}_{2}$ using flow injection analysis (FIAstar Analyzer 5000, FOSS) at the Cornell Craft Beverage Analytical Laboratory (New York State Agricultural Experiment Station, Geneva, NY). Lemberger wine samples were analyzed for color intensity and hue as described (Zoecklein et al. 1995).

TNCs. Concentrations of TNC (starch and soluble sugars) were measured in canes, trunks, and roots during vine acclimation. Two vines per experimental unit were sampled on 12 Nov 2018 and 11 Nov 2019. Two internode sections were cut from the base of two canes per vine. Trunk tissue was collected by drilling three holes using a $3.57 \mathrm{~mm}$ drill bit into the bottom, middle, and uppermost portion of the trunk and removing the collected trunk material from the drill bit flute. Lignified roots between 1 and $4 \mathrm{~mm}$ in diameter were collected from shallow soil layers $(0$ to $20 \mathrm{~cm})$ at both sides of the vine. All cane, trunk, and root samples were immediately placed on dry ice for transport and stored at $-80^{\circ} \mathrm{C}$ until processing. Root samples were washed with de-ionized water to remove debris and any fine, absorptive root $(<1 \mathrm{~mm}$ diameter) was trimmed before storage.

Tissues were lyophilized for one week at $-50^{\circ} \mathrm{C}$ and 0.100 mbar (FreeZone 12 Liter Freeze Dryer, Labconco) before TNC extraction. Once dried, cane and root samples were ground using a mill with a $1.0 \mathrm{~mm}$ mesh sieve (Wiley Model 4 Mill, Thomas Scientific), while trunk samples were hand-ground using a mortar and pestle. TNC concentration was determined using the protocol outlined in Comas et al. (2005), with a spectrophotometer at $520 \mathrm{~nm}$ (UV1600, VWR International). TNC concentrations are expressed in glucose equivalents.

Bud freeze tolerance. Bud freeze tolerance was determined during vine acclimation (November), at maximum freeze tolerance (midwinter; January or February), and during deacclimation (March or April) using differential thermal analysis (DTA) as described (Mills et al. 2006). This method detects the low-temperature exotherm (LTE) created by the freezing of intracellular water, which is lethal to the cell (Burke et al. 1976). Four healthy Lemberger canes per experimental unit were sampled on the following dates: 6 Nov 2018 and 11 Nov 2019, 28 Jan 2019 and 20 Jan 2020, and 9 April 2019 and 25 March 2020. Riesling canes were sampled on: 8 Nov 2018 and 11 Nov 2019, 7 Feb 2019 and 20 Jan 2020, and 9 April 2019 and 25 March 2020. Bud freeze tolerance was measured on the same day samples were collected, except for the Riesling acclimation sampling in 2019, midwinter sampling dates in both years, and deacclimation sampling in 2020. In these instances, half the samples of each block were measured on the same day they were collected and half on the following day, with canes stored in a $2^{\circ} \mathrm{C}$ walk-in cooler overnight or at ambient temperature $\left(10^{\circ} \mathrm{C}\right)$ for Riesling midwinter sampling in 2019.

To measure bud freeze tolerance, nodes 3 and 4 on each cane were excised with a razorblade and placed in thermoelectric modules on trays (Melcor Corporation). Four buds were placed in each module, and two modules were used for each experimental unit in each DTA run. The trays were placed in a temperature-controlled freezer chamber (Tenney, Thermal Product Solutions), and temperature was lowered slowly to $-40^{\circ} \mathrm{C}$ as described (Mills et al. 2006). Bud freeze tolerance for each experimental unit was estimated as the median low-temperature exotherm $\left(\mathrm{LT}_{50}\right)$ : the temperature at which $50 \%$ of sampled buds died (Mills et al. 2006).

Bud survival and fruitfulness. Bud survival was assessed on the same cordons used for the phenology assessment on 29 May 2018 for both cultivars and on 3 and 4 June 2019 for Lemberger and Riesling, respectively, prior to shoot-thinning. Bud survival was calculated as the percentage of total buds that opened. Carryover treatment effects were evaluated the year after the 2018 and 2019 treatment applications on 3 June 2019 and 6 June 2020, respectively. The number of live buds, shoots, and clusters per shoot were measured on each cordon of the vines used for phenological measurements, and the percentages of live buds and clusters per shoot (bud fruitfulness) were calculated.

Statistical analysis. All data analysis was performed using SAS statistical software (SAS Institute, Inc.) All viticulture data were subjected to analysis of variance (ANOVA) using the MIXED procedure with block included as a random effect. All viticulture data were analyzed separately by year to assess vine response to a spring freeze event, which occurred in one of the two years of the study (2019). Tukey's honest significant difference test was used to identify significant treatment differences at the 0.05 alpha level. Data collected under field conditions can be quite variable, and a large sample size (over 10 blocks) may be needed to detect differences at the 5\% level (Marini 1999); therefore, we elected to report exact pairwise comparison $p$ values to assist the reader in data interpretation.

Lemberger wine chemical data was analyzed similarly to viticulture data, as wine was fermented in biological triplicate. For Riesling wine chemistry, biological replicates could not be maintained, and wine was fermented in duplicate; therefore, differences among treatments were not analyzed statistically and only standard errors are reported.

\section{Results}

Weather conditions. Cumulative GDD between $50 \%$ budbreak and harvest were similar between the two growing 
seasons: 1706 GDD in 2018 and 1689 GDD in 2019 for Lemberger control vines and 1635 GDD in 2018 and 1612 GDD in 2019 for Riesling control vines. Cumulative GDD from budbreak to harvest for Lemberger treatments were 39 (Amigo $8 \%$ in 2018) to 74 (late pruning in 2018) GDD less than the control; for Riesling, the range varied from 13 (Amigo 8\% in 2018) to 76 (late pruning in 2018) fewer GDD than control vines (data not shown). Rainfall from May through September was almost double in $2018(836 \mathrm{~mm})$ than in $2019(480 \mathrm{~mm})$. The summer of 2019 (July to September) was relatively dry, with only $187 \mathrm{~mm}$ total rainfall, while 2018 was much wetter with $617 \mathrm{~mm}$ rainfall. There was a freezing event on 29 April 2019; temperatures decreased below $0^{\circ} \mathrm{C}$ starting at $0200 \mathrm{hr}$ and did not increase above $0^{\circ} \mathrm{C}$ until $0600 \mathrm{hr}$. The minimum temperature reached during this period was $-2.0^{\circ} \mathrm{C}$ at $0500 \mathrm{hr}$. About $40 \%$ of the control buds were at or beyond budbreak (E-L 5) at the time of the freezing event (Figure 1D).

Grapevine budbreak and phenology. Amigo and late pruning treatments delayed budbreak compared to the control in both cultivars and years (Figures 1 and 2). In Lemberger, control vines reached 50\% budbreak $\sim 9$ May 2018 and 6 May 2019, while those treated with Amigo 8\% and
$10 \%$ reached $50 \%$ budbreak six and seven days later in 2018 ( $p=0.012$ and $p=0.005$, respectively) and five days later in $2019(p=0.030)$ (Table 1). Late-pruned Lemberger vines reached $50 \%$ budbreak 10 days later than the control in both years $(p<0.001)$. In general, there were no significant differences in phenological growth stage between Lemberger vines treated with Amigo 8\% or $10 \%$; therefore, results of the two Amigo treatments will be discussed together.

Control vines had a greater percentage of buds at or beyond budbreak than Amigo 8\% and Amigo 10\% through 15 May 2018 ( $p=0.028$ and $p=0.019$, respectively) and $\sim 15$ May 2019 ( $p=0.034$ and $p=0.072$, respectively) (Figure $1 \mathrm{C}$ and $1 D)$. The delay in rate of budbreak was more pronounced for late pruning than for Amigo treatments; control vines had a significantly higher percentage of buds at or beyond budbreak than late-pruned vines through 21 May $2018(p=0.003)$ and 23 May $2019(p=0.016)$ (Figure 1C and 1D).

The delay in phenological development of late-pruned Lemberger vines was visible at veraison (Table 2), while differences between Amigo and control vines disappeared by bloom (Figure 1A and 1B). Specifically, the Amigo treatments were still behind in phenological development when
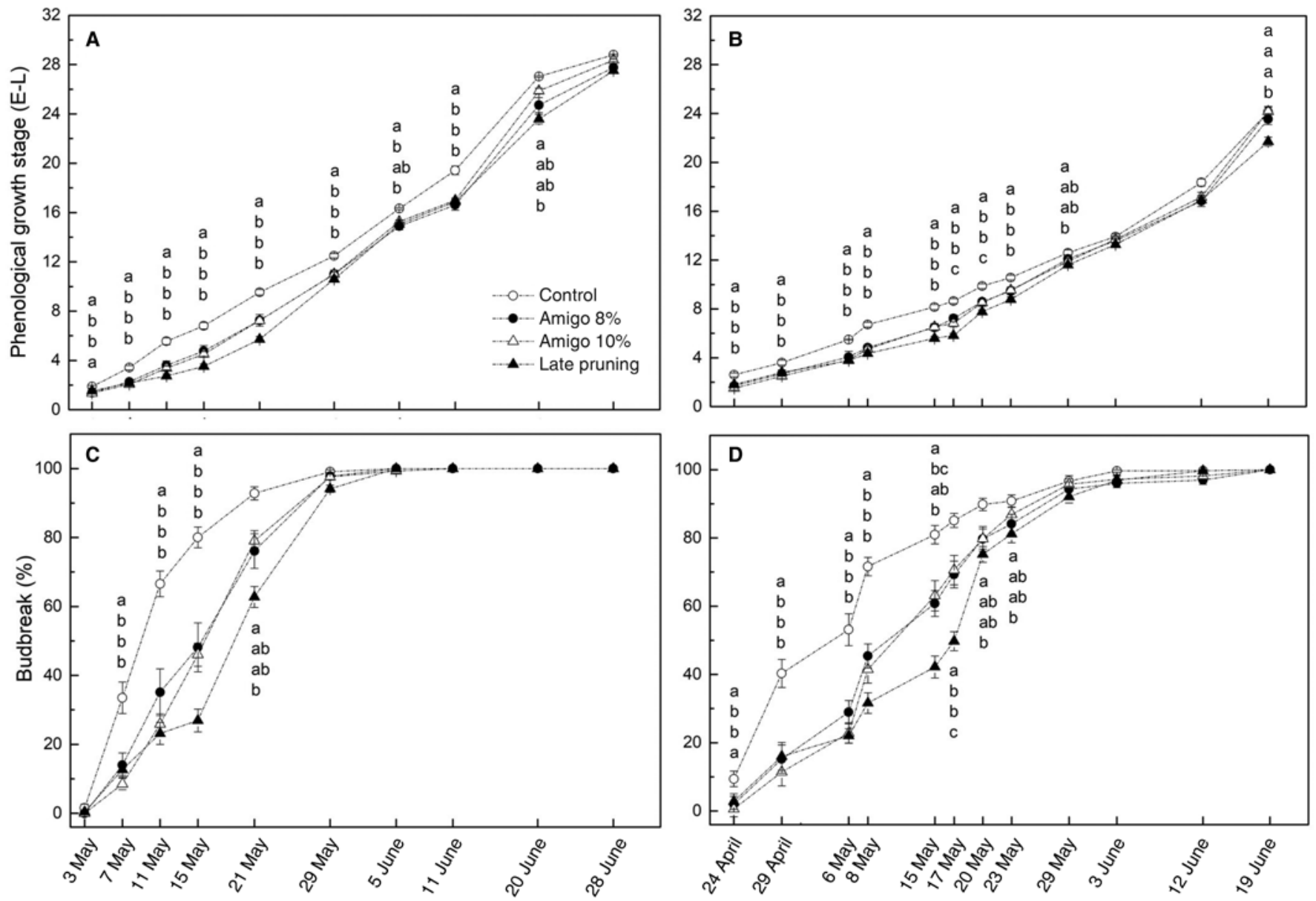

Figure 1 Average phenological growth stage of Lemberger vines in 2018 (A) and 2019 (B) and percentage of buds that reached budbreak (EichhornLorenz [E-L] 5) in 2018 (C) and 2019 (D) at each sampling date. Treatments were a control (no delayed budbreak strategy applied), Amigo applied during dormancy at $8 \%$ or $10 \%(\mathrm{v} / \mathrm{v})$, and late pruning applied when the three-most-apical buds averaged stage 7 on the E-L scale. For each date, different letters indicate differences between treatments based on Tukey's honest significant difference test at 95\% confidence. Letters of significance are ordered from top-down at each date as follows: 1) Control, 2) Amigo 8\%, 3) Amigo 10\%, and 4) Late pruning. 
the control was at E-L 19 "beginning of flowering" in 2018 (control versus Amigo 8\%, $p=0.008$; control versus Amigo $10 \%, p=0.024)$ and E-L 11 "four leaves separated" in 2019 (control versus Amigo 8\%, $p=0.006$; control versus Amigo $10 \%, p=0.009)$. The phenological delay of the late pruning treatment was more pronounced than Amigo treatments: late-pruned vines were still significantly different than control vines when the control was at fruit set (E-L 27) in 2018 $(p=0.010)$ and past full bloom (E-L 23) in $2019(p=0.006)$. The veraison visual assessment indicated that in mid-August, a greater percentage of berries had changed color in the control than in late-pruned clusters in both years, while differences between Amigo and control treatments were not significant or consistent between years (Table 2).

In Riesling, vines treated with Amigo 8\% and 10\% reached $50 \%$ budbreak three and six days later than control vines in 2018 ( $p=0.249$ and $p=0.004$, respectively) and six and eight days later in 2019 ( $p=0.050$ and $p=0.013$, respectively; Table 1). Late-pruned Riesling vines reached $50 \%$ budbreak 11 (2018) and 10 (2019) days after the control vines (2018 and 2019; $p<0.001$; Table 1). In 2018, Riesling control vines had a greater percentage of buds at or beyond budbreak than Amigo 10\% through 21 May ( $p=0.023$ ), but there were no differences between the control and Amigo 8\% treatments (Figure 2C). In comparison, in 2019, control vines had a greater percentage of buds at or beyond budbreak through 14 May for Amigo 8\% $(p=0.007)$ and 20 May for Amigo 10\% $(p=0.025)$ (Figure 2D). Late-pruned Riesling vines had the lowest percentage of buds at or beyond budbreak, remaining lower than the control through 21 May $2018(p<0.001)$ and 4 June 2019 ( $p=0.008$ ), except for 30 May 2019, when the percentage of budbreak did not differ among treatments (Figure $2 \mathrm{C}$ and 2D). Late pruning and Amigo 10\% delayed phenological development compared to control vines in Riesling, but there were no consistent differences between Amigo 8\% and control vines (Figure 2A and 2B). Phenological growth stage of late-pruned vines remained behind the control through the last day of measurements in both years, while Amigo $10 \%$ lagged on the last measurement in 2019 only. In 2019, Amigo $10 \%$ and late pruning vines were at E-L 20, "0\% caps off," while control vines were already past full bloom, E-L 23 ( $p=0.017$ and $p=0.037$, respectively) on the last day of measurements (Figure 2B).

Freeze damage. On 29 April 2019, the day of the spring freeze event, $40 \%$ of Lemberger control buds were at budbreak (E-L 5), while only 15, 11, and 16\% of Amigo 8\%, Amigo 10\%,
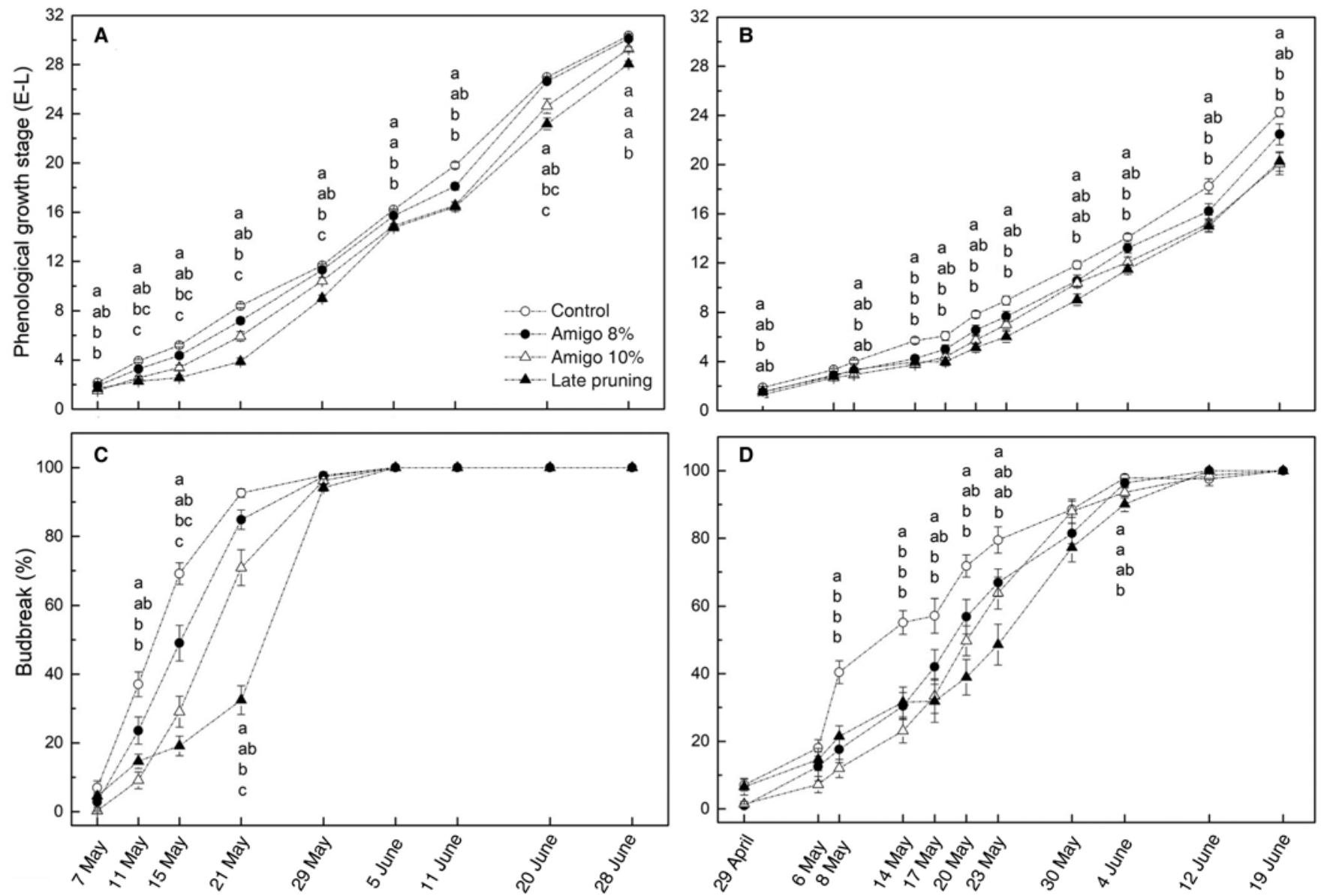

Figure 2 Average phenological growth stage of Riesling vines in 2018 (A) and 2019 (B) and percentage of buds that reached budbreak (Eichhorn-Lorenz [E-L] 5) in 2018 (C) and 2019 (D) at each sampling date. Treatments were a control (no delayed budbreak strategy applied), Amigo applied during dormancy at $8 \%$ or $10 \%(\mathrm{v} / \mathrm{V})$, and late pruning applied when the three-most-apical buds averaged stage 7 on the E-L scale, except for Riesling buds in 2018, which averaged E-L 9. For each date, different letters indicate differences between treatments based on Tukey's honest significant difference test at 95\% confidence. Letters of significance are ordered from top-down at each date as follows: 1) Control, 2) Amigo 8\%, 3) Amigo 10\%, and 4) Late pruning. 
and late-pruned buds were at budbreak, respectively (control versus each delayed budbreak treatment, $p<0.001$; Figure 1D). In Riesling, less than $10 \%$ of the buds were at budbreak, regardless of treatment; the average growth stage was around E-L 3 "woolly bud," thus green tissue was not yet visible (Figure 2B). The post-freeze damage assessment indicated Lemberger control vines had a significantly higher percentage of shoots with visible green tissue damage than late-pruned vines

Table 1 Dates of $50 \%$ budbreak and harvest for Lemberger and Riesling grapevines at the experimental vineyard in 2018 and 2019.

\begin{tabular}{|c|c|c|c|c|}
\hline \multirow[b]{2}{*}{ Treatment $^{\mathrm{a}}$} & \multicolumn{2}{|c|}{2018} & \multicolumn{2}{|c|}{2019} \\
\hline & $\begin{array}{l}\text { Date of } 50 \% \\
\text { budbreak }\end{array}$ & $\begin{array}{l}\text { Date of } \\
\text { harvest }\end{array}$ & $\begin{array}{l}\text { Date of } 50 \% \\
\text { budbreak }\end{array}$ & $\begin{array}{l}\text { Date of } \\
\text { harvest }\end{array}$ \\
\hline \multicolumn{5}{|l|}{ Lemberger } \\
\hline Control & 9 May $a^{b}$ & $3 \mathrm{Oct}$ & 6 May a & $4 \mathrm{Oct}$ \\
\hline Amigo $8 \%$ & 15 May b & & 11 May b & \\
\hline Amigo $10 \%$ & 16 May b & & 11 May b & \\
\hline Late pruning & 19 May b & & 16 May c & \\
\hline$p$ value & $<0.001$ & & $<0.001$ & \\
\hline \multicolumn{5}{|l|}{ Riesling } \\
\hline Control & 12 May a & 26 Sept & 13 May a & 30 Sept \\
\hline Amigo $8 \%$ & 15 May a & & 19 May b & \\
\hline Amigo $10 \%$ & 18 May b & & 21 May b & \\
\hline Late pruning & 23 May c & & 23 May b & \\
\hline$p$ value & $<0.001$ & & 0.004 & \\
\hline
\end{tabular}

${ }^{a}$ Treatments were a control (no delayed budbreak strategy applied), Amigo applied during dormancy at $8 \%$ or $10 \%(\mathrm{v} / \mathrm{v})$, and late pruning applied when the three-most-apical buds averaged stage 7 on the Eichhorn-Lorenz (E-L) scale, except for Riesling buds in 2018, which averaged E-L 9.

'Treatment means within columns followed by different letters are significantly different based on Tukey's honest significant difference test at $95 \%$ confidence.
(58\% and $31 \%$ of total shoots, respectively; $p=0.004$ ). The control also tended to have a higher percentage of shoots with visible damage $(58 \%)$ than Amigo $8 \%(42 \%, p=0.098)$ and Amigo $10 \%$ (41\%, $p=0.067$; data not shown).

Yield components and pruning weight. Treatment effects on yield components at harvest varied between cultivars (Table 3). In Lemberger, Amigo and late pruning treatments did not affect yield components in 2018. In 2019, the year with a spring freeze, late-pruned vines had $61 \%$ greater yield than control vines $(p=0.038)$; although there were no significant differences in yield components, the number of clusters per vine tended to be greater in the late-pruned vines than in control vines $(p=0.077)$. In contrast, late pruning negatively affected Riesling average cluster and berry weight in both years, while production parameters of Amigo and control vines did not differ (Table 3). In 2018, late-pruned Riesling vines had less yield than control vines $(p=0.027)$, likely attributed to lower berry weight ( $p=0.023)$ and fewer berries per cluster $(p=0.074)$.

Amigo and late pruning treatments did not affect vine vegetative growth, assessed through pruning weights, in either cultivar or year (Table 3). Overall, crop load indices were low for both cultivars and years (data not shown). In 2018, Ravaz indices did not differ across treatments and ranged from 1.32 (control) to 2.40 (late pruning) for Lemberger and from 2.47 (Amigo 8\%) to 3.15 (control) for Riesling. In 2019, Lemberger Ravaz indices ranged from 1.75 (control) to 2.68 (late pruning; control versus late pruning, $p=0.063$ ). Ravaz indices for Riesling 2019 were very low, ranging from 0.67 (late Pruning) to 1.11 (Amigo 10\%), but crop load was not affected by the treatments.

Juice and wine chemistry. In both cultivars, juice chemistry (TSS, $\mathrm{pH}$, and TA) during ripening did not consistently or significantly vary across treatments (harvest data shown in

Table 2 Effect of Amigo and late pruning treatments on Lemberger percent veraison in mid-August and Lemberger and Riesling juice chemistry at harvest. TSS, total soluble solids; TA, titratable acidity.

\begin{tabular}{|c|c|c|c|c|c|c|c|c|}
\hline \multirow[b]{2}{*}{ Treatment $^{\mathrm{b}}$} & \multicolumn{2}{|c|}{ Veraison $^{\mathrm{a}}(\%)$} & \multicolumn{2}{|c|}{ TSS (Brix) } & \multicolumn{2}{|c|}{$\mathrm{pH}$} & \multicolumn{2}{|c|}{ TA (g/L) } \\
\hline & 2018 & 2019 & 2018 & 2019 & 2018 & 2019 & 2018 & 2019 \\
\hline \multicolumn{9}{|l|}{ Lemberger } \\
\hline Control & $80 a^{c}$ & $75 a$ & 18.2 & 23.5 & 3.59 & 3.56 & 7.79 & 6.62 \\
\hline Amigo 8\% & $51 \mathrm{~b}$ & $74 a$ & 18.2 & 22.3 & 3.57 & 3.50 & 7.88 & 6.44 \\
\hline Amigo $10 \%$ & $58 a b$ & $74 \mathrm{a}$ & 17.0 & 22.5 & 3.60 & 3.54 & 7.38 & 6.66 \\
\hline Late pruning & $37 \mathrm{~b}$ & $53 \mathrm{~b}$ & 18.4 & 23.5 & 3.54 & 3.54 & 8.40 & 6.38 \\
\hline$p$ value & $<0.001$ & 0.009 & 0.420 & 0.192 & 0.148 & 0.516 & 0.340 & 0.361 \\
\hline \multicolumn{9}{|l|}{ Riesling } \\
\hline Control & $N / A^{d}$ & $N / A$ & 15.5 & 18.6 & 3.42 & $3.46 a b$ & $8.71 \mathrm{ab}$ & 7.49 \\
\hline Amigo 8\% & N/A & $N / A$ & 15.5 & 18.9 & 3.39 & $3.43 \mathrm{~b}$ & $8.89 a b$ & 7.74 \\
\hline Amigo 10\% & $N / A$ & $N / A$ & 14.8 & 18.5 & 3.37 & $3.54 \mathrm{a}$ & $8.39 \mathrm{~b}$ & 7.69 \\
\hline Late pruning & $\mathrm{N} / \mathrm{A}$ & $\mathrm{N} / \mathrm{A}$ & 15.3 & 17.9 & 3.34 & $3.36 \mathrm{~b}$ & $9.39 \mathrm{a}$ & 8.40 \\
\hline$p$ value & & & 0.726 & 0.496 & 0.063 & 0.006 & 0.022 & 0.176 \\
\hline
\end{tabular}

apercentage of berries per cluster that changed color measured on 15 Aug 2018 and 15 Aug 2019.

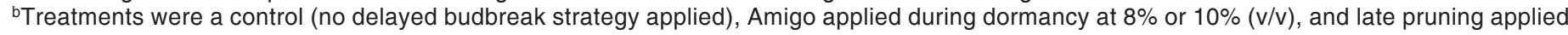
when the three-most-apical buds averaged stage 7 on the Eichhorn-Lorenz (E-L) Scale, except for Riesling buds in 2018, which averaged E-L 9. 'Treatment means within columns followed by different letters are significantly different based on Tukey's honest significant difference test at $95 \%$ confidence.

${ }^{\mathrm{d} R}$ Riesling berry color-change was not measured. 
Table 2). The only significant differences among treatments at harvest was higher juice TA of late-pruned Riesling vines than Amigo 10\% in $2018(p=0.015)$ and lower $\mathrm{pH}$ of Amigo 8\% and late-pruned vines than Amigo 10\% in 2019 ( $p=0.041$ and $p=0.004$, respectively; Table 2). Wine chemistry confirmed harvest juice chemistry results; there were no significant differences among treatments for any parameter analyzed $(\mathrm{pH}, \mathrm{TA}$, alcohol, color intensity, and hue) in Lemberger wines (Table 4).

TNCs. The delayed budbreak treatments did not decrease TNC concentration in canes, trunks, or roots in November (Table 5). In 2019, canes of Lemberger control vines had significantly lower concentration of TNC than all other treat- ments (Amigo 8\%: $p=0.018$; Amigo 10\%: $p<0.001$; late pruning: $p=0.004)$.

Bud freeze tolerance. Overall, treatments did not consistently affect bud freeze tolerance throughout dormancy in either cultivar (Table 6). In 2018 only, $\mathrm{LT}_{50}$ of Amigo and late-pruned Lemberger vines was between 2.1 (Amigo 8\%) and $2.6^{\circ} \mathrm{C}$ (late pruning) greater than that of the control in November (Amigo 8\%: $p=0.024$; Amigo 10\%: $p=0.008$; late pruning: $p=0.005)$. These differences were not significant by January 2019.

Bud survival and fruitfulness. In both years, Riesling vines treated with Amigo 10\% had less bud survival than

\begin{tabular}{|c|c|c|c|c|c|c|c|c|c|c|c|c|}
\hline \multirow[b]{2}{*}{ Treatment $^{\mathrm{a}}$} & \multicolumn{2}{|c|}{$\begin{array}{c}\text { Yield } \\
\text { (kg/vine) }\end{array}$} & \multicolumn{2}{|c|}{$\begin{array}{c}\text { Clusters/vine } \\
\text { (n) }\end{array}$} & \multicolumn{2}{|c|}{$\begin{array}{l}\text { Cluster wt } \\
\text { (g) }\end{array}$} & \multicolumn{2}{|c|}{$\begin{array}{l}\text { Berry wt } \\
\text { (g) }\end{array}$} & \multicolumn{2}{|c|}{$\begin{array}{l}\text { Berries/cluster } \\
\text { (n) }\end{array}$} & \multicolumn{2}{|c|}{$\begin{array}{c}\text { Pruning wt } \\
\text { (kg/vine) }\end{array}$} \\
\hline & 2018 & 2019 & 2018 & 2019 & 2018 & 2019 & 2018 & 2019 & 2018 & 2019 & 2018 & 2019 \\
\hline \multicolumn{13}{|l|}{ Lemberger } \\
\hline Control & 2.60 & $2.03 \mathrm{~b}^{\mathrm{b}}$ & $19 \mathrm{~b}$ & 15 & 139 & 139 & 1.82 & 1.83 & 76 & 77 & 1.47 & 1.63 \\
\hline Amigo $8 \%$ & 2.86 & $3.02 a b$ & $22 a b$ & 19 & 129 & 157 & 1.80 & 1.86 & 71 & 84 & 1.24 & 1.44 \\
\hline Amigo $10 \%$ & 2.96 & $2.72 a b$ & $24 \mathrm{a}$ & 17 & 125 & 154 & 1.77 & 1.72 & 71 & 90 & 1.18 & 1.44 \\
\hline Late pruning & 3.24 & $3.27 \mathrm{a}$ & $25 \mathrm{a}$ & 21 & 130 & 151 & 1.86 & 1.72 & 70 & 87 & 1.23 & 1.44 \\
\hline$p$ value & 0.150 & 0.045 & 0.011 & 0.094 & 0.679 & 0.404 & 0.551 & 0.379 & 0.550 & 0.344 & 0.103 & 0.231 \\
\hline \multicolumn{13}{|l|}{ Riesling } \\
\hline Control & $3.52 \mathrm{a}$ & 1.12 & 33 & 13 & $107 \mathrm{a}$ & $79 a$ & $1.97 \mathrm{a}$ & $2.06 \mathrm{a}$ & 55 & $39 a b$ & 1.15 & 1.42 \\
\hline Amigo $8 \%$ & $3.05 a b$ & 1.27 & 35 & 15 & $86 a b$ & $87 \mathrm{a}$ & $1.94 \mathrm{a}$ & $1.88 a b$ & 44 & $46 a b$ & 1.24 & 1.33 \\
\hline Amigo $10 \%$ & $2.96 a b$ & 1.51 & 33 & 16 & $88 a b$ & 95 a & $1.95 \mathrm{a}$ & $1.86 a b$ & 45 & $53 \mathrm{a}$ & 1.00 & 1.38 \\
\hline Late pruning & $2.28 \mathrm{~b}$ & 0.75 & 31 & 12 & $73 \mathrm{~b}$ & $52 \mathrm{~b}$ & $1.76 \mathrm{~b}$ & $1.60 \mathrm{~b}$ & 43 & $33 \mathrm{~b}$ & 0.92 & 1.11 \\
\hline$p$ value & 0.027 & 0.171 & 0.542 & 0.645 & 0.012 & 0.003 & 0.018 & 0.010 & 0.081 & 0.023 & 0.309 & 0.161 \\
\hline
\end{tabular}

${ }^{a}$ Treatments were a control (no delayed budbreak strategy applied), Amigo applied during dormancy at $8 \%$ or $10 \%$ (v/v), and late pruning applied when the three-most-apical buds averaged stage 7 on the Eichhorn-Lorenz (E-L) scale, except for Riesling buds in 2018 , which averaged E-L 9. ${ }^{\mathrm{b}}$ Treatment means within columns followed by different letters are significantly different based on Tukey's honest significant difference test at $95 \%$ confidence.

Table 4 Effect of Amigo and late pruning treatments on Lemberger and Riesling on wine composition at bottling, vintage 2018 and 2019. TA, titratable acidity.

\begin{tabular}{|c|c|c|c|c|c|c|c|c|c|c|}
\hline \multirow[b]{2}{*}{ Treatment $^{\mathrm{b}}$} & \multicolumn{2}{|c|}{$\mathrm{pH}$} & \multicolumn{2}{|c|}{$\begin{array}{l}\text { TA } \\
\text { (g/L) }\end{array}$} & \multicolumn{2}{|c|}{$\begin{array}{c}\text { Alcohola }_{(\%)} \\
\text { (\%) }\end{array}$} & \multicolumn{2}{|c|}{$\begin{array}{l}\text { Color intensity } \\
\text { (Au) }\end{array}$} & \multicolumn{2}{|c|}{$\begin{array}{c}\text { Color hue } \\
\text { (Au/Au) }\end{array}$} \\
\hline & 2018 & 2019 & 2018 & 2019 & 2018 & 2019 & 2018 & 2019 & 2018 & 2019 \\
\hline \multicolumn{11}{|l|}{ Lemberger } \\
\hline Control & 3.76 & 3.86 & $5.23 \mathrm{a}^{\mathrm{c}}$ & 5.53 & 10.9 & 12.6 & 2.46 & 2.23 & 1.21 & 1.03 \\
\hline Amigo 8\% & 3.79 & 3.78 & $4.90 \mathrm{~b}$ & 5.60 & 10.7 & 12.5 & 2.18 & 2.24 & 1.18 & 0.93 \\
\hline Amigo $10 \%$ & 3.75 & 3.78 & $4.90 \mathrm{~b}$ & 5.67 & 10.7 & 12.5 & 2.40 & 2.06 & 1.10 & 0.98 \\
\hline Late pruning & 3.72 & 3.76 & $5.20 \mathrm{a}$ & 5.50 & 10.8 & 12.7 & 2.27 & 2.16 & 1.24 & 0.90 \\
\hline$p$ value & 0.396 & 0.427 & 0.011 & 0.902 & 0.939 & 0.763 & 0.529 & 0.756 & 0.381 & 0.759 \\
\hline \multicolumn{11}{|l|}{ Riesling } \\
\hline Control & $N / A^{d}$ & $3.21 \pm 0.01^{\mathrm{e}}$ & $\mathrm{N} / \mathrm{A}$ & $7.55 \pm 0.15$ & $\mathrm{~N} / \mathrm{A}$ & $11.8 \pm 0.1$ & $\mathrm{~N} / \mathrm{A}$ & $N / A^{f}$ & $\mathrm{~N} / \mathrm{A}$ & $\mathrm{N} / \mathrm{A}$ \\
\hline Amigo 8\% & N/A & $3.20 \pm 0.01$ & $\mathrm{~N} / \mathrm{A}$ & $7.75 \pm 0.05$ & $\mathrm{~N} / \mathrm{A}$ & $12.1 \pm 0.1$ & $\mathrm{~N} / \mathrm{A}$ & N/A & $\mathrm{N} / \mathrm{A}$ & $\mathrm{N} / \mathrm{A}$ \\
\hline Amigo $10 \%$ & N/A & $3.17 \pm 0.05$ & $\mathrm{~N} / \mathrm{A}$ & $7.65 \pm 0.05$ & $\mathrm{~N} / \mathrm{A}$ & $11.8 \pm 0.1$ & $\mathrm{~N} / \mathrm{A}$ & $\mathrm{N} / \mathrm{A}$ & $\mathrm{N} / \mathrm{A}$ & $\mathrm{N} / \mathrm{A}$ \\
\hline Late pruning & N/A & $3.17 \pm 0.05$ & $N / A$ & $7.75 \pm 0.05$ & $\mathrm{~N} / \mathrm{A}$ & $11.1 \pm 0.1$ & $\mathrm{~N} / \mathrm{A}$ & $\mathrm{N} / \mathrm{A}$ & $\mathrm{N} / \mathrm{A}$ & $\mathrm{N} / \mathrm{A}$ \\
\hline
\end{tabular}

aLemberger must was chaptalized to 21 Brix with granulated sucrose prior to inoculation in 2018 . Riesling juice was chaptalized to 21 Brix with granulated sucrose prior to inoculation in 2019. Lemberger must was not chaptalized in 2019.

${ }^{\mathrm{b}}$ Treatments were a control (no delayed budbreak strategy applied), Amigo applied during dormancy at $8 \%$ or $10 \%$ (v/v), and late pruning applied when the three-most-apical buds averaged stage 7 on the Eichhorn-Lorenz (E-L) scale, except for Riesling buds in 2018, which averaged E-L 9. 'Lemberger wines were fermented in biological triplicate; means within columns followed by different letters are significantly different based on Tukey's honest significant difference test at $95 \%$ confidence.

${ }^{\mathrm{d}}$ Riesling wine was not made in 2018.

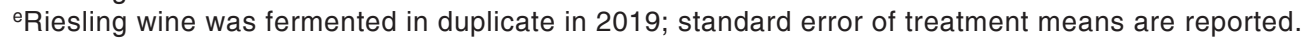

${ }^{f}$ Color intensity and hue were not measured for Riesling (white wine). 
control vines. In 2018, Riesling vines treated with Amigo $10 \%$ had $82.4 \%$ bud survival, while control vines had $91.8 \%$ bud survival ( $p=0.042$ ). In 2019, bud survival was $59.2 \%$ for Amigo $10 \%$ and $73.6 \%$ for control vines ( $p=0.045$; data not shown). Lemberger bud survival did not differ among treatments in either year and ranged from $82.4 \%$ (control) to $90.2 \%$ (late pruning) in 2018, and from $74.8 \%$ (Amigo 8\%) to $83.8 \%$ (control) in 2019 (data not shown). There were no carryover effects the year after treatment application. The percentage of live buds and bud fruitfulness did not differ between vines assigned to control and delayed budbreak treatments the previous year for either cultivar (data not shown).

\section{Discussion}

In general, our results indicated Amigo and late pruning consistently delayed grapevine budbreak. The delay in budbreak was most pronounced and consistent between years in late-pruned vines than in those treated with Amigo 8\% or $10 \%$. Consequently, late pruning was most effective in mitigating grapevine freeze damage. Our findings on the effects of Amigo and late pruning on delaying budbreak support previous research conducted on $V$. vinifera cultivars. For instance, Amigo 10\% applied during dormancy to Riesling and Lemberger grown at the same site of our study delayed budbreak between six and 11 days (Centinari et al. 2018). Rapeseed oil applied to Grüner Veltliner and Zweigelt delayed

Table 5 Effect of Amigo and late pruning treatments on total non-structural carbohydrate concentration in Lemberger and Riesling cane, trunk, and root tissues during vine acclimation in November 2018 and 2019. Concentrations are reported in mg glucose equivalents per $\mathrm{g}$ dry tissue weight.

\begin{tabular}{|c|c|c|c|c|c|c|}
\hline \multirow[b]{2}{*}{ Treatment $^{\mathrm{a}}$} & \multicolumn{2}{|c|}{ Cane $(\mathrm{mg} / \mathrm{g})$} & \multicolumn{2}{|c|}{ Trunk (mg/g) } & \multicolumn{2}{|c|}{ Root $(\mathrm{mg} / \mathrm{g})$} \\
\hline & 2018 & 2019 & 2018 & 2019 & 2018 & 2019 \\
\hline \multicolumn{7}{|l|}{ Lemberger } \\
\hline Control & 78.5 & $55.7 b^{b}$ & 57.8 & 62.4 & 81.3 & 121.0 \\
\hline Amigo $8 \%$ & 79.7 & $63.1 \mathrm{a}$ & 56.5 & 55.7 & 90.1 & 123.6 \\
\hline Amigo $10 \%$ & 85.0 & $67.6 \mathrm{a}$ & 54.5 & 57.8 & 88.3 & 115.3 \\
\hline Late pruning & 81.6 & $64.7 \mathrm{a}$ & 54.9 & 63.1 & 92.8 & 109.8 \\
\hline$p$ value & 0.411 & $<0.001$ & 0.583 & 0.098 & 0.160 & 0.753 \\
\hline \multicolumn{7}{|l|}{ Riesling } \\
\hline Control & 73.0 & 61.8 & 59.6 & 46.9 & $N / A^{c}$ & $\mathrm{~N} / \mathrm{A}$ \\
\hline Amigo 8\% & 78.4 & 59.9 & 62.5 & 43.3 & $\mathrm{~N} / \mathrm{A}$ & $\mathrm{N} / \mathrm{A}$ \\
\hline Amigo $10 \%$ & 75.5 & 63.9 & 61.8 & 45.8 & $\mathrm{~N} / \mathrm{A}$ & $\mathrm{N} / \mathrm{A}$ \\
\hline Late pruning & 75.1 & 60.6 & 66.8 & 46.1 & N/A & $\mathrm{N} / \mathrm{A}$ \\
\hline$p$ value & 0.307 & 0.841 & 0.383 & 0.547 & & \\
\hline
\end{tabular}

Treatments were a control (no delayed budbreak strategy applied), Amigo applied during dormancy at $8 \%$ or $10 \%$ (v/v), and late pruning applied when the three-most-apical buds averaged stage 7 on the Eichhorn-Lorenz (E-L) scale, except for Riesling buds in 2018, which averaged E-L 9. bTreatment means within columns followed by different letters are significantly different based on Tukey's honest significant difference test at $95 \%$ confidence.

'Vine undergrowth prohibited accurate root sampling of Riesling.

Table 6 Effect of Amigo and late pruning treatments on bud median low-temperature exotherm $\left({ }^{\circ} \mathrm{C}\right)$ for Riesling and Lemberger vines at acclimation (November), maximum freeze tolerance (January or February), and deacclimation (March or April) during the 2018 to 2019 and 2019 to 2020 dormant seasons.

\begin{tabular}{|c|c|c|c|c|c|c|}
\hline Treatment $^{\mathrm{a}}$ & & & & & & \\
\hline Lemberger & November 2018 & November 2019 & January 2019 & January 2020 & April 2019 & March 2020 \\
\hline Control & $-17.10 b^{b}$ & -17.43 & -22.33 & 22.28 & -11.02 & -13.82 \\
\hline Amigo $8 \%$ & $-15.00 \mathrm{a}$ & -17.61 & -20.35 & -22.60 & -10.45 & -13.77 \\
\hline Amigo $10 \%$ & $-14.67 \mathrm{a}$ & -17.79 & -22.53 & -22.53 & -12.03 & -14.08 \\
\hline Late pruning & $-14.48 \mathrm{a}$ & -17.78 & -22.90 & -22.91 & -11.25 & -13.99 \\
\hline$p$ value & $<0.003$ & 0.751 & 0.078 & 0.825 & 0.427 & 0.936 \\
\hline Riesling & November 2018 & November 2019 & February 2019 & January 2020 & April 2019 & March 2020 \\
\hline Control & -15.12 & -19.35 & -22.95 & -22.85 & -10.42 & -15.92 \\
\hline Amigo $8 \%$ & -15.14 & -19.02 & -23.99 & -22.95 & -10.85 & -16.11 \\
\hline Amigo $10 \%$ & -14.11 & -18.96 & -22.30 & -23.18 & -9.83 & -16.34 \\
\hline Late pruning & -14.63 & -19.03 & -22.78 & -22.80 & -10.60 & -15.85 \\
\hline$p$ value & 0.191 & 0.951 & 0.142 & 0.908 & 0.326 & 0.764 \\
\hline
\end{tabular}

aTreatments were a control (no delayed budbreak strategy applied), Amigo applied during dormancy at $8 \%$ or $10 \%$ (v/v), and late pruning applied when the three-most-apical buds averaged except for Riesling buds in 2018, which averaged E-L 9.

'Treatment means within columns followed by different letters are significantly different based on Tukey's honest significant difference test at $95 \%$ confidence. 
budbreak between five and 12 days, respectively (Herrera et al. 2018). These ranges, with few exceptions (see for example, Riesling with Amigo 8\% in 2018) are similar to what we reported for the Amigo treatments. Several factors can influence the efficacy of vegetable oil-based adjuvants in delaying budbreak, including cultivars (i.e., Vitis hybrids versus $V$. vinifera), time of application during dormancy, and weather conditions prior to budbreak (Loseke et al. 2015, Centinari et al. 2018, Wang and Dami 2020). Cultivars with relatively late budbreak may benefit from later application of Amigo during dormancy (Dami and Beam 2004), and an early application may increase the chance of oil weathering by rainfall. More research is required to clarify the effect of weather conditions (i.e., heat accumulation and rainfall) after Amigo application on year-to-year variation in budbreak delay.

In comparison to applications of vegetable oil-based adjuvants, the extent of delay induced by late pruning is mostly attributed to the phenological stage of the apical buds at the time of removal (Frioni et al. 2016, Gatti et al. 2016). Late pruning applied at a similar phenological stage to our study (between two-to-three leaves unfolded) delayed budbreak from 17 days (Gatti et al. 2016) in Sangiovese vines, to four weeks or more (Moran et al. 2017, Frioni et al. 2019) in Pinot noir and Shiraz vines, respectively, compared to standard pruning. Delays in budbreak in late-pruned vines were less pronounced in our study, but still consistent between years and cultivars. Among several factors, including chilling requirement and genotype (Londo and Johnson 2014), different temperatures around the time of budbreak may explain different results across studies. Although our research was conducted in a cool climate, it is possible that at our site, temperatures around the time of budbreak were higher than in northern Italy and Australia (Gatti et al. 2016, Moran et al. 2017), leading to a shorter delay in budbreak between control and late-pruned vines. In our study, budbreak of Lemberger and Riesling control vines occurred approximately three to four weeks later than reported in northern Italy (Gatti et al. 2016).

Delayed budbreak in the Amigo and late pruning treatments delayed subsequent key phenological stages. In Lemberger, differences between the late pruning and control treatments were still visible at veraison, while differences in phenology between the Amigo treatments and control tended to converge by bloom. In Riesling, differences between the control and late pruning treatments were observed through bloom, and Amigo 10\% tended to be more effective in delaying phenology than $8 \%$. These delays in phenology did not correspond to treatment differences in berry ripening. In agreement with our hypothesis, there were no effects of Amigo or late pruning on fruit and wine chemistry compared to control vines. Our results support previous studies on Amigo, where the extent of delayed budbreak was similar to what we observed (i.e., 11 days or less), and there were no effects on juice or wine chemistry in either $V$. vinifera (Centinari et al. 2018) or hybrid cultivars (Dami and Beam 2004). Previous research on the effects of late pruning on juice chemistry reported less TSS accumulation and higher TA in berries during ripening (Frioni et al. 2016, 2019); however, these differences were observed when pruning was performed at a later phenological stage (Frioni et al. 2016) or when a more extensive delay in budbreak was reported (Frioni et al. 2019) than in our study. Similarly, differences in wine chemistry between late pruning and control treatments were reported when delays in budbreak were more extensive (i.e., over two weeks) than under our study conditions (Moran et al. 2018).

We hypothesized that preferential allocation of photosynthates to vegetative and reproductive growth might reduce TNC storage in perennial tissues, especially if the delay in budbreak was extensive. However, there was no evidence of reduced TNC concentration or related negative carryover effects, such as lower bud freeze tolerance, in response to delayed budbreak. It is possible that leaves of Amigo and late-pruned vines had increased net photosynthetic efficiency (Gatti et al. 2016), which may have supplied sufficient photosynthate for both fruit ripening and storage by fall. Alternatively, the delays in phenology were too modest to cause a photosynthate "deficit" strong enough to affect fruit development or TNC storage; however, late pruning may have altered source-sink relationships earlier in the season, reducing fruit set in Riesling, as discussed below.

The efficacy of late pruning to mitigate freeze damage, without negatively affecting within-season and postharvest parameters, is relevant to regions where spring freeze events are a recurring issue. In 2019, Lemberger late-pruned vines had $61 \%$ greater yield than control vines, reflecting differences in shoot freeze damage between the two treatments. Freezing temperatures may have killed a greater percentage of young shoots in the control, leaving less-fruitful secondary buds to develop (Friend et al. 2011); alternatively, freezing temperatures may have damaged inflorescences in buds and young primary shoots (Centinari et al. 2016). Freeze damage did not affect fruit or wine chemistry but may have reduced TNC accumulation in canes of control vines at the end of the season (November) due to damage to vegetative growth and a potential reduction in carbon assimilation. Although Amigo and late-pruned vines appeared to be at a similar phenological stage on the day of the freeze event, the ability of late pruning to reduce freeze damage (i.e., prevent vegetative tissue damage and crop loss) was more pronounced with late pruning than Amigo treatments. It is plausible that slight differences in bud development were not detectable at such early phenological stages; this is supported by the fact that Amigo-treated vines achieved budbreak earlier than late-pruned vines. It is worth noting that while Amigo treatments did not mitigate crop loss, they reduced vegetative damage in Lemberger compared to control vines to some degree.

Throughout our study, there were no negative effects of Amigo application on yield components in Lemberger or Riesling. Late pruning had no detrimental effect in Lemberger, but it negatively affected several yield components in Riesling (i.e., reduced cluster and berry weight). Previous studies have reported conflicting effects of late pruning on crop yield. Depending on location, cultivar, and time of application, late winter pruning decreased (Frioni et al. 2016, 
Gatti et al. 2016, Petrie et al. 2017), increased (Friend and Trought 2007, Moran et al. 2017, Petrie et al. 2017), or did not affect crop yield (Frioni et al. 2016, Moran et al. 2017). In our study, late-pruned Riesling vines had lower berry weight than the control in both years, which could be attributed to a delayed or shorter "Stage 1" of berry ripening, when the relative increase in berry fresh weight increases rapidly (Staudt et al. 1986). Fewer berries per cluster in response to late pruning has been reported elsewhere (Frioni et al. 2016, Gatti et al. 2016), but the mechanism behind this reduction is not clear. Late-pruned vines tended to have fewer berries per cluster than the control in the first season of our study $(p=0.074)$. Possible explanations for fewer berries per cluster in latepruned vines include compromised flower development in basal buds or decreased fruit set in response to late pruning. Growth of apical buds in late-pruned vines may have limited carbohydrate availability to basal buds, reducing their floral development (Mason et al. 2014); alternatively, a carbohydrate deficit induced by late pruning may have prompted vines to prioritize vegetative growth over fruit set, as reported when prebloom leaf removal is implemented (Frioni et al. 2018). Future studies could explore effects of late pruning on flower development, fertilization, and berry growth, which, at least under our experimental conditions, varied between cultivars and vintages.

Crop load values in our study for both cultivars and years were below the range (four to 10) suggested for optimal vine balance (Kliewer and Dokoozlian 2005). Vines were overly vegetative, likely due to the high-vigor potential of the site and possible winter cold damage, specifically for Riesling in 2019, when crop load was low regardless of treatment. Although not directly quantified, the overall low yield and number of clusters per vine in Riesling may be associated with winter cold damage prior to the second study year. The lowest winter temperature was $-19^{\circ} \mathrm{C}$ on 31 Jan 2019 , and, based on $\mathrm{LT}_{10}$ (data not shown) and $\mathrm{LT}_{50}$ data of the 2018 experimental vines collected three days earlier (Lemberger) and a week later (Riesling), we did not expect extensive bud damage in either cultivar. However, the vines used in 2019 were in different rows than the vines used in 2018, and the 2019 vines may have experienced winter cold damage, resulting in a lower-than-expected overall bud survival. Percent of bud survival for Riesling control vines was, indeed, 91.8\% in 2018 , but $73.6 \%$ in 2019 . However, neither Amigo application nor late pruning affected the inherent vigor of Riesling or Lemberger vines, and these treatments had no relevant or consistent effect on the crop load.

Application of Amigo 10\% consistently reduced bud survival in Riesling compared to control vines, supporting previous work (Centinari et al. 2018). In that study, oil phytotoxicity together with below-average winter temperatures were suggested as potential causes for reduced bud survival of Amigo-treated vines. In our study, it is possible the higher concentration of Amigo (10\%) induced excessive $\mathrm{CO}_{2}$ or endogenous hormone accumulation in buds, eventually causing reduced bud survival when measured later in the season. The effect of Amigo $10 \%$ on bud survival was cultivar-specific; moreover, reduced bud survival was not significant enough to negatively affect other parameters (e.g., yield or pruning weight) in Riesling vines treated with Amigo 10\%.

\section{Conclusion}

Amigo and late pruning treatments tended to delay budbreak in both years and cultivars in our study. Late pruning provided the most consistent and extensive delay in budbreak and subsequent phenological stages. Furthermore, late-pruned Lemberger vines sustained significantly less freeze damage and had greater yield than control vines in the year with a freeze event. There were several drawbacks of Amigo application and late pruning on Riesling vines, suggesting cultivar-dependent responses should be tested and expected. There were no negative effects of Amigo application on within-season or postharvest parameters in Lemberger; however, the extent of delay in phenological growth can be less predictable in Amigo-treated vines, and, in our study, it was not large enough to cause a significant reduction in freeze damage. Testing Amigo on a small number of vines is suggested; this could also limit the cost of application (material and labor) which could be prohibitive for some growers. Late pruning applied relatively soon post-apical budbreak (i.e., E-L 7) may be a more reliable method to delay budbreak for cordon-trained vines. Because it is a labor-intensive practice, late pruning is best suited for small, freeze-prone areas of the vineyard.

\section{Literature Cited}

Burke MJ, Gusta LV, Quamme HA, Weiser CJ and Li PH. 1976. Freezing injury in plants. Ann Rev Plant Physiol 27:507-528.

Candolfi-Vasconcelos MC, Candolfi MP and Koblet W. 1994. Retranslocation of carbon reserves from the woody storage tissues into the fruit as a response to defoliation stress during the ripening period in Vitis vinifera L. Planta 192:567-573.

Centinari M, Smith MS and Londo JP. 2016. Assessment of freeze injury of grapevine green tissues in response to cultivars and a cryoprotectant product. HortScience 51:856-860.

Centinari M, Gardner DM, Smith DE and Smith MS. 2018. Impact of Amigo oil and KDL on grapevine postbudburst freeze damage, yield components, and fruit and wine composition. Am J Enol Vitic 69:77-88

Comas LH, Anderson LJ, Dunst RM, Lakso AN and Eissenstat DM. 2005. Canopy and environmental control of root dynamics in a longterm study of Concord grape. New Phytol 167:829-840.

Coombe BG. 1995. Adoption of a system for identifying grapevine growth stages. Aust J Grape Wine Res 1:104-110.

Dami IE and Beam BA. 2004. Response of grapevines to soybean oil application. Am J Enol Vitic 55:269-275.

Evans RG. 2000. The art of protecting grapevines from low temperature injury. In Proceedings of the ASEV 50th Anniversary Annual Meeting. Rantz (ed.), pp. 60-72. Seattle, WA.

Ferguson JC, Tarara JM, Mills LJ, Grove GG and Keller M. 2011. Dynamic thermal time model of cold hardiness for dormant grapevine buds. Ann Bot 107:389-396.

Ferguson JC, Moyer MM, Mills LJ, Hoogenboom G and Keller M. 2014. Modeling dormant bud cold hardiness and budbreak in twentythree Vitis genotypes reveals variation by region of origin. Am J Enol Vitic 65:59-71. 
Friend AP and Trought MCT. 2007. Delayed winter spur-pruning in New Zealand can alter yield components of Merlot grapevines. Aust J Grape Wine Res 13:157-164.

Friend AP, Trought MCT, Stushnoff C and Wells GH. 2011. Effect of delaying budburst on shoot development and yield of Vitis vinifera L. Chardonnay 'Mendoza' after a spring freeze event. Aust J Grape Wine Res 17:378-382.

Frioni T, Tombesi S, Silvestroni O, Lanari V, Bellincontro A, Sabbatini P, Gatti M, Poni S and Palliotti A. 2016. Postbudburst spur pruning reduces yield and delays fruit sugar accumulation in Sangiovese in central Italy. Am J Enol Vitic 67:419-425.

Frioni T, Acimovic D, Tombesi S, Sivilotti P, Palliotti A, Poni S and Sabbatini P. 2018. Changes in within-shoot carbon partitioning in Pinot noir grapevines subjected to early basal leaf removal. Front Plant Sci 9:1122.

Frioni T, Pirez FJ, Diti I, Ronney L, Poni S and Gatti M. 2019. Postbudbreak pruning changes intra-spur phenology dynamics, vine productivity and berry ripening parameters in Vitis vinifera L. cv. 'Pinot noir.' Sci Hortic 256:108584.

Gardea AA, Moreno YM, Azarenko AN, Lombard PB, Daley LS and Criddle RS. 1994. Changes in metabolic properties of grape buds during development. J Am Soc Hortic Sci 119:756-760.

Gatti M, Pirez FJ, Chiari G, Tombesi S, Palliotti A, Merli MC and Poni S. 2016. Phenology, canopy aging and seasonal carbon balance as related to delayed winter pruning of Vitis vinifera L. cv. Sangiovese grapevines. Front Plant Sci 7:659.

Herrera J, Knöbl R, Gabler C, Kührer E and Forneck A. 2018. Effect of vegetal oil application on budbreak phenology timing. Mitt Klosterneuburg 68:172-180.

Holzapfel BP, Smith JP, Field SK and Hardie WJ. 2010. Dynamics of carbohydrate reserves in cultivated grapevines. In Horticultural Reviews. Vol. 37. Janick J (ed.), pp. 143-211. Wiley-Blackwell.

Homich LJ, Elias RJ, Vanden Heuvel JE and Centinari M. 2017. Impact of fruit-zone leaf removal on rotundone concentration in Noiret. Am J Enol Vitic 68:447-457.

Howell GS and Wolpert JA. 1978. Nodes per cane, primary bud phenology, and spring freeze damage to Concord grapevines. A preliminary note. Am J Enol Vitic 29:229-232.

Jones KS, Paroschy J, Mckersie BD and Bowley SR. 1999. Carbohydrate composition and freezing tolerance of canes and buds in Vitis vinifera. J Plant Physiol 155:101-106.

Kliewer WM and Dokoozlian NK. 2005. Leaf area/crop weight ratios of grapevines: Influence on fruit composition and wine quality. Am J Enol Vitic 56:170-181.
Kovaleski AP and Londo JP. 2019. Tempo of gene regulation in wild and cultivated Vitis species shows coordination between cold deacclimation and budbreak. Plant Sci 287:110178.

Londo JP and Johnson LM. 2014. Variation in the chilling requirement and budburst rate of wild Vitis species. Environ Exp Bot 106:138-147.

Loseke BA, Read PE and Blankenship EE. 2015. Preventing spring freeze injury on grapevines using multiple applications of Amigo oil and naphthaleneacetic acid. Sci Hortic 193:294-300.

Marini RP. 1999. Are nonsignificant differences really not significant? HortScience 34:761-762

Mason MG, Ross JJ, Babst BA, Wienclaw BN and Beveridge CA. 2014. Sugar demand, not auxin, is the initial regulator of apical dominance. P Natl Acad Sci USA 111:6092-6097.

Mills LJ, Ferguson JC and Keller M. 2006. Cold-hardiness evaluation of grapevine buds and cane tissues. Am J Enol Vitic 57:194-200.

Moran MA, Sadras VO and Petrie PR. 2017. Late pruning and carryover effects on phenology, yield components and berry traits in Shiraz. Aust J Grape Wine Res 23:390-398.

Moran MA, Bastian SE, Petrie PR and Sadras VO. 2018. Late pruning impacts on chemical and sensory attributes of Shiraz wine. Aust J Grape Wine Res 24:469-477.

Palliotti A, Frioni T, Tombesi S, Sabbatini P, Cruz-Castillo JG, Lanari V, Silvestroni O, Gatti M and Poni S. 2017. Double-pruning grapevines as a management tool to delay berry ripening and control yield. Am J Enol Vitic 68:412-421.

Petrie PR, Brooke SJ, Moran MA and Sadras VO. 2017. Pruning after budburst to delay and spread grape maturity. Aust J Grape Wine Res 23:378-389.

Staudt G, Schneider W and Leidel J. 1986. Phases of berry growth in Vitis vinifera. Ann Bot 58:789-800.

Wang H and Dami IE. 2020. Evaluation of budbreak-delaying products to avoid spring frost injury in grapevines. Am J Enol Vitic 71:181-190.

Warmund MR, Guinan P and Fernandez G. 2008. Temperatures and cold damage to small fruit crops across the eastern United States associated with the April 2007 freeze. HortScience 43:1643-1647.

Wolf TK. 2008. Wine Grape Production Guide for Eastern North America. Natural Resource, Agriculture, and Engineering Service (NRAES) Cooperative Extension, Ithaca, NY.

Zoecklein BW, Fugelsang KC, Gump BH and Nury FS. 1995. Laboratory procedures. In Wine Analysis and Production. pp. 310-516. Springer, New York. 